\title{
Homocysteine: validation and comparison of two methods using samples from patients with pulmonary hypertension
}

\author{
Homocisteína: validação e comparação entre dois métodos utilizando \\ amostras de pacientes com hipertensão pulmonar
}

Tatiana Maria Costa de Campos Barbosa ${ }^{1}$; Maria das Graças Carvalho²; Josianne Nicácio Silveira³; Júnia Garib Rios; Flávia Komatsuzaki; Lara Carvalho Godóíi; Guilherme Hideki Yoshizane Costa ${ }^{7}$

\begin{abstract}
Introduction and objective: The determination of homocysteine plasma levels has been reported as a risk marker of interest in severe diseases involving endothelial injury and associated with the development or progression of atherosclerotic lesions and thrombus formation. The aims of this study were to validate method for quantification of plasma homocysteine by high performance liquid chromatography (HPLC) with fluorimetric detection, and to compare the results obtained from patients with pulmonary hypertension by HPLC with those obtained by spectrophotometric enzymatic cycling (S-Ec) method. Materials and methods: The validation parameters, such as linearity, matrix effect, precision, accuracy, detection and quantitation limits, and robustness of the method were evaluated aiming to demonstrate that it is suitable for the intended use. The data obtained in the quantification of homocysteine using the validated method (HPLC) and the spectrophotometric enzymatic cycling (S-Ec) method, were compared. Results: The method was precise, accurate, and robust; it also had good recovery and showed no matrix effect. The linearity covered a range of 5.0-85.0 $\mu \mathrm{mol} / \mathrm{l}$ and the limits of detection and quantification were $1.0 \mu \mathrm{mol} / \mathrm{l}$ and $3.4 \mu \mathrm{mol} / \mathrm{l}$, respectively. The results obtained for homocysteine determination by HPLC and S-Ec methods were comparable. Conclusion: The validated HPLC method showed good performance for quantification of plasma homocysteine levels, while S-Ec method provided results for homocysteine comparable with those obtained by the validated method; therefore, this methodology is a potential alternative of automated method for clinical laboratories.
\end{abstract}

Key words: homocysteine; high performance liquid chromatography; spectrophotometric enzymatic cycling method.

\section{INTRODUCTION}

Homocysteine is a sulfur amino acid formed during the metabolism of methionine from diet or endogenous proteins degradation ${ }^{(10,18,22)}$. Published research hypothesized that increased plasma homocysteine levels favors the occurrence of diseases, such as acute myocardial infarction, thrombosis, and atherosclerosis disease $^{(11,12,16,17)}$. Hyperhomocysteinemia can be inherited and/or acquired. The main genetic disorders are due to mutations in the methylenetetrahydrofolate reductase or cystathionine ß-synthase enzymes, while the acquired causes include of vitamins B6 and B12 or folate deficiencies, advanced age, chronic kidney disease, and use of antifolate ${ }^{(24)}$. It is believed that hyperhomocysteinemia may cause changes on vascular endothelium, mainly mediated by the toxic effect of oxidized forms of this amino $\mathrm{acid}^{(2)}$. The evaluation of plasma homocysteine levels has been reported as a biomarker for endothelial dysfunction, linking its increase to severe diseases with endothelial injury, such as pulmonary hypertension $(\mathrm{PH})^{(3)}$,

First submission on $03 / 08 / 14$; last submission on 13/11/14; accepted for publication on 13/11/14; published on 20/12/14

1. MSc in Pharmaceutical Sciences by Universidade Federal de Minas Gerais (UFMG); student at the Department of Clinical and Toxicological Analysis of the School of PharmacyUFMG.

2. Postdoctoral in Hemostasis by Maastricht University, The Netherlands; full professor at the Department of Clinical and Toxicological Analysis of the School of Pharmacy-UFMG.

3. PhD in Analytical Chemistry by UFMG; professor at the Department of Clinical and Toxicological Analysis of the School of Pharmacy-UFMG.

4. MSc in Clinical Medicine by Santa Casa de Belo Horizonte; pulmonolgist at the Medical Specialist Center of Santa Casa de Belo Horizonte.

5. MSc in Statistics by UFMG; responsible for the statistical analysis of the projects of the Department of Clinical and Toxicological Analysis of the School of Pharmacy-UFMG.

6. PhD in Pharmaceutical Sciences by UFMG; research and development coordinator of Labtest Diagnóstica S.A. group.

7. Pharmacist by Universidade Federal de Ouro Preto; junior researcher of Labtest Diagnóstica S.A. group. 
which is characterized by pulmonary arterial hypertension, and may reflect in dysfunction and right ventricular heart failure ${ }^{(4)}$.

Some studies involving the evaluation of plasma homocysteine levels in patients with pulmonary hypertension, associated or not with other diseases, are described in the literature ${ }^{(3,19,25)}$. However, the knowledge from other parts of the world are not always reflection of local conditions, since genetic and epidemiological variables can affect the manifestation of $\mathrm{PH}$.

Homocysteine determination can be performed by many analytical techniques. Among them, high-performance liquid chromatography (HPLC) highlights, considered by many authors as a reference technique for the determination of this amino $\operatorname{acid}^{(7,9,14,23)}$. The sensitivity and specificity attributed to HPLC technique contribute to consider it the gold standard, however, due to the need for technical expertise on the operation of the equipment, its use is limited in the laboratory routine ${ }^{(8,25)}$. Other techniques, such as chemiluminescence, spectrophotometric enzymatic cycling (S-Ec), and immunoassay can also be used to determine plasma homocysteine levels, and represent an alternative for the clinical laboratory, with the benefits of being partially or fully automated ${ }^{(0,15)}$. It is noteworthy to highlight the S-Ec, an automated technique which, through system amplification by a enzyme-catalyzed reaction, allows to quantify homocysteine quickly and with quality.

To ensure that a new analytical method can produce reliable results on the sample, the laboratory should ensure by validation that the performance characteristics of the method meet the requirements for the intended analytical operations ${ }^{(1,21)}$. There are technical, legal, and commercial reasons justifying the implementation of validation, the available validation manuals suggest guidelines to follow, open to interpretation. In Brazil, the National Health Surveillance Agency (Agência Nacional de Vigilância Sanitária [ANVISA]) and the National Institute of Metrology, Quality, and Technology (Instituto Nacional de Metrologia, Qualidade e Tecnologia [INMETRO]) provide the guidelines on how to conduct validation by the Resolution RDC 27 from 17 May, 2012 and the DOC-CGCRE-008 from July, 2011 (5, 13).

Some parameters for method validation are evaluated, including linearity, range or linear range, selectivity (matrix effect), accuracy, precision, detection limit, quantification limit, and robustness ${ }^{(13)}$. The investigation of the matrix effect on the quantification of compounds is an important parameter to be evaluated in the development and validation of bioanalytical methods, if this is not ensured, linearity, trend, and accuracy will be seriously damage ${ }^{(6,13)}$.

The objectives of this study were to validate the plasma HPLC method for quantification of homocysteine, including parameters such as linearity, matrix effect, detection limit, quantification limit, precision, accuracy and robustness of the method, and then, to compare the homocysteine results obtained by HPLC from sample of patients with $\mathrm{PH}$ with those obtained by S-Ec method (Labtest kit).

\section{MATERIALS AND METHODS}

\section{Standards, chemicals, and controls}

The standards and chemicals used in validated HPLC method were acquired from Sigma Aldrich ${ }^{\mathrm{TM}}$ (St Louis, USA), and include DL-Homocysteine 95\% pure; cystamine dihydrochloride (internal standard); tris (2-carboxyethyl) phosphine hydrochloride ([TCEP], reducing agent); 7-fluorobenzo-2,1,3-oxadiazole-4-sulfonic acid ([SBDF], derivatizing agent) $98 \%$ pure, and phosphate buffered saline system (PBS), pH 7.4. Regarding the controls, we used Liquichek $^{\mathrm{TM}}$ Homocysteine Control, level 1 (7.3-12.1 $\left.\mu \mathrm{mol} / \mathrm{l}\right)$ and level 2 (22.6-33.8 $\mu \mathrm{mol} / \mathrm{l})$, lot 34900, Biorad ${ }^{\mathrm{TM}}$, (Irvine, USA), as internal control, in addition to Interlaboratory Program CR-A 2011 (Cardiac Risk), number 7206871-01, identification Kit 23958451, College of American Pathology (CAP) (Northfield, USA).

\section{Reagents}

The reagents used were from Merck ${ }^{\mathrm{TM}}$ (Darmstadt, Germany), J.T. Baker $^{\mathrm{TM}}$ (Mexico), and Vetec ${ }^{\mathrm{TM}}$ (Duque de Caxias, Brazil), including glacial acetic acid (HPLC grade); trichloroacetic acid ([TCA], analytical grade); boric acid (analytical grade); ethylenediaminetetraacetic acid ([EDTA], analytical grade); sodium acetate trihydrate (analytical grade); sodium hydroxide ([NaOH], analytical grade), and methanol (HPLC grade). We used deionized water from Millipore $^{\mathrm{TM}}$ purification system (Millipore, Bedford, MA, USA), with resistivity of 18.2 megaohms.cm. The reagents used in the comparative study were: Calibra Homocysteine, Qualitrol Homocysteine, and the Homocysteine Kit provided by Labtest Diagnóstica S.A.

\section{Determination of plasma homocisteine by HPLC}

We used the HP - model 1100 - HPLC system by Agilent Technologies (Santa Clara, USA), equipped with isocratic pump, thermostat, automatic injector, fluorometric detector, model 1200; the system was controlled by ChemStation software.

The solutions were prepared as follows:

a) homocysteine storage standard solution $2.000,0 \mu \mathrm{mol} / \mathrm{l}$ and cysteine storage standard solution (internal standard [IS]) $705 \mu \mathrm{mol} / \mathrm{l}$ in deionized water; 
b) homocysteine aqueous intermediate standard solutions (concentrations: 50.0; 100.0; 150.0; 200.0; 250.0; 300.0; 350.0; $400.0 ; 450.0 ; 500.0 ; 650.0 ; 750.0 ; 800.0 ; 850.0 ; 1050.0$, and 1250.0 $\mu \mathrm{mol} / \mathrm{l})$ were prepared from the homocysteine storage standard solution. The homocysteine standard solutions were prepared in water and matrix (concentrations: 5.0; 10.0; 15.0; 20.0; 25.0; $30.0 ; 35.0 ; 40.0 ; 45.0 ; 50.0 ; 65.0 ; 75.0 ; 80.0 ; 85.0 ; 105.0$, and 125.0 $\mu \mathrm{mol} / \mathrm{l})$, from the respective intermediary standard solutions. Cysteine aqueous intermediary standard solution 20,0 $\mu \mathrm{mol} / \mathrm{l}$ was prepared from cysteine storage standard solution and cysteine standard solutions $10,0 \mu \mathrm{mol} / \mathrm{l}$ aqueous, from the cysteine intermediate standard solution;

c) other solutions used in the methodology include sodium hydroxide $0.39 \mathrm{~mol} / \mathrm{l}$ and $5.0 \mathrm{~mol} / \mathrm{l}$ solutions; borate EDTA buffer solution, $\mathrm{pH} 9.5$ (3.86 g of boric acid; $0.74 \mathrm{~g}$ of EDTA for $500.0 \mathrm{ml}$ of solution); TCEP $25.0 \mathrm{~g} / \mathrm{l}$ solution; SBDF $1,0 \mathrm{~g} / \mathrm{l}$ solution; PBS solution prepared according to manufacturer's orientation; and TCA-EDTA solution ( $5.0 \mathrm{~g}$ of TCA, $0.0186 \mathrm{~g}$ of EDTA for $50.0 \mathrm{ml}$ solution);

d) plasma pool: homogenized, aliquoted, and stored at $-20^{\circ} \mathrm{C}$ until the moment of use.

\section{Preparation of mobile phase and cromatographic conditions}

The mobile phase consisted of acetate buffer $(6.80 \mathrm{~g}$ of sodium acetate and $2.9 \mathrm{ml}$ of acetic acid for 1.01 of solution), $\mathrm{pH}$ 5.5 adjusted with $\mathrm{NaOH} 5.0 \mathrm{~mol} / \mathrm{l}$, flow $1.1 \mathrm{ml} / \mathrm{min}$; Techsphere chromatographic column C18 $(15 \mathrm{~cm} \times 4.6 \mathrm{~mm} ; 5 \mu \mathrm{m})$ by Sun SRI ${ }^{\mathrm{TM}}$ (Welwyn Garden, USA); injection volume of $50 \mu \mathrm{l}$; fluorimetric detector: $\lambda_{\text {ex }}=385 \mathrm{~nm}$ and $\lambda_{\mathrm{em}}=515 \mathrm{~nm}$. The total chromatographic run time was 9 minutes.

\section{Method of analysis}

The proposed method was described by Pfeiffer et al. $(1999)^{(20)}$ with some modifications, and initially consisted of reduction thiol groups by TCEP in the protein precipitation and then, derivatization of homocysteine by SBDF.

We added to eppendorf $50 \mu \mathrm{l}$ of plasma or homocysteine standard solution, $40 \mu \mathrm{l}$ of standard solution of IS, $25 \mu \mathrm{l}$ of PBS, and $40 \mu \mathrm{l}$ of TCEP. The wating time for thiol groups' reduction reaction was 30 minutes. After 30 minutes, $90 \mu$ of precipitanting agent TCA-EDTA was added, the solution was shaken for $30 \mathrm{sec}$ and centrifuged at $13.000 \mathrm{~g}$ for $10 \mathrm{~min}$ at $24^{\circ} \mathrm{C}$. The supernatant was removed and $50 \mu \mathrm{l}$ transferred to an amber tube, to which was added $40 \mu \mathrm{l}$ of NaOH $0.39 \mathrm{~mol} / \mathrm{l}, 125 \mu \mathrm{l}$ of borate EDTA buffer and $50 \mu \mathrm{l}$ of SBDF. The solution was homogenized and incubated for $60 \mathrm{~min}$ in water bath at $60^{\circ} \mathrm{C}$. An aliquot of $50 \mu \mathrm{l}$ of this solution was injected into the chromatograph.

\section{Stability of derivatized sample}

The concentrations 5.0; 25.0; 65.0, and $105.0 \mu \mathrm{mol} / \mathrm{l}$ were prepared in independent sextuplicates. The samples were submitted to the analysis method previously described, with injection in the preparation day (Group 1) and reinjection after 24 hours (Group 2).

Data were processed comparing the relative areas obtained in Groups 1 and 2. Mann Whitney test was performed by the Statistical Package for the Social Sciences Software 12.0 (SPSS 12.0).

\section{Method validation}

The validation parameters described below were evaluated, and statistical tools were applied with the aid of SPSS 12.0 and Minitab 16.0 softwares.

\section{Linearity}

The concentrations 5.0; 25.0; 45.0; 65.0; 85.0; 105.0 e 125.0 $\mu \mathrm{mol} / \mathrm{l}$ were prepared in independent quintuplicates, in water and matrix, and processed as described at Method of analysis topic. The outliers' verification was performed by Boxplot; thhe normality was verified by the Shapiro Wilk test; and linear regression was verified by analysis of variance (ANOVA).

\section{Matrix effect}

For the study of matrix effect, we used the same curves proposed for linearity. The range considered linear and the one used for matrix effext analysis was 5.0 to $85.0 \mu \mathrm{mol} / \mathrm{l}$ of homocisteine. The analytical curves were built, the residues were calculated, and the variances of the curves in matrix and aqueous curves were evaluated by Levene's test and $t$-test aiming to verify the matrix interference.

\section{Precision}

The concentrations $10.0 ; 15.0 ; 30.0 ; 40.0$ e $75.0 \mu \mathrm{mol} / 1$ were prepared at different quintiplicates and processed as described in topic Method of analysis. The solutions were analyzed by chromatography on the same day of preparation (intra-assay 
precision), and on three consecutive days (inter-assay precision). The intra-assay and inter-assay precision were expressed by the coefficient of variation.

Another way to evaluate the partial inter-assay precision was varying analysts (two) in two days using the samples of studied patients. In this regard, ten samples were prepared in duplicate on each day of analysis. Standard solutions of use, calibration curves, and controls were prepared for each analyst, separately. For statistical analysis of inter-assay precision, initially we performed the calculation of differences on concentration of each duplicate of analyzed sample, and for each analyst separately. Using the differences we could verify the normality of results by AndersonDarling test, and then, $t$-test to verify the equality of differences between analysts.

\section{Accurac}

The concentrations 10.0; 15.0; 30.0; 40.0, and $75.0 \mu \mathrm{mol} / \mathrm{l}$ were prepared in independent quintuplicates and processed as described in topic Method of Analysis. The accuracy of the method was verified by the means of apparent recoveries obtained by adding samples at each concentration level. The recovery rates were calculated according to DOC-CGCRE-000 ${ }^{(13)}$.

Accuracy was also verified by the assertiveness in the Interlaboratorial Program of College of American Pathology (CAP), CR-A 2011 (Cardiac Risk), which contains three levels of different concentrations. Samples were processed in duplicate on the same day.

Accuracy was also evaluated on each day of experiment by Bio-Rad internal controls (two concentration levels). The results were evaluated taking into account the range of concentration informed for each level in the reported issued by manufacturer.

\section{Limit of detection and quantification}

To evaluate the method limits of detection (LD) and quantification (LQ), 10 independent replicates were prepared from white plasma pool. The solutions were processed as described in the topic Method of Analysis. The limits of detection and quantification were calculated according to DOCCGCRE-008 ${ }^{(13)}$.

\section{Robustness}

Small variations in method were proposed in order to evaluate the robustness. This study assessed seven analytical parameters: addition of methanol in the mobile phase, concentrations of SBDF, TCEP, and TCA-EDTA, number of revolutions, centrifugation time, and water bath temperature. Nominal values and variations are shown in Table 1.

TABLE 1 - Analytical parameters in the nominal condition and in the variations proposed in the robustness test

\begin{tabular}{cccc}
\hline & Parameters & Nominal & Variation \\
\hline A & Methanol in mobile phase & $0 \%$ & $1 \%$ \\
B & SBDF & $1 \mathrm{~g} / \mathrm{g}$ & $0.9 \mathrm{~g} / \mathrm{l}$ \\
$\mathrm{C}$ & Rotation & $13.000 \mathrm{~g}$ & $14.000 \mathrm{~g}$ \\
$\mathrm{D}$ & Water bath temperature & $60^{\circ} \mathrm{C}$ & $65^{\circ} \mathrm{C}$ \\
$\mathrm{E}$ & TCA-EDTA & $100 \mathrm{~g} / \mathrm{l}+1 \mathrm{mmol} / \mathrm{l}$ & $110 \mathrm{~g} / \mathrm{l}+1.1 \mathrm{mmol} / \mathrm{l}$ \\
$\mathrm{F}$ & TCEP & $25 \mathrm{~g} / \mathrm{l}$ & $20 \mathrm{~g} / \mathrm{l}$ \\
$\mathrm{G}$ & Rotation time & 10 minutes & 7 minutes \\
\hline SBDF: 7-fluorobenzo-2,1,3-oxadiazole-4-sulfonic acid; TCA-EDTA: trichloroacetic acid- \\
ethylenediaminetetraacetic acid; TCEP: tris (2-carboxyethyl) phosphine hydrochloride.
\end{tabular}

The experiment was conducted in accordance with Youden's test ${ }^{(13)}$, in which the seven seleted analytical parameters ( A, B, C, D, E, F, and G) were placed in eight tests arranged by the combinatorial analysis and randomly evaluated. From these eight tests, four were performed with each parameter at its nominal value and four with the variations. We compared the mean of the four values corresponding to nominal parameters with the average of the four values corresponding to variations, in order to determine the influence of variation of each parameter in the final result.

Data were statistically evaluated and organized in Group 1 the four values of each parameter at its nominal value, and Group 0 - the four values of each parameter at its variation. The normality was verified using the Shapiro WilK test. Then, F-test and $t$-test were performed.

\section{Sampling and blood colection}

Patients were aged between 19-80 years, of both sexes, and diagnosed with $\mathrm{PH}$ by the responsible pulmonolgist at specific outpatient Medical Specialties Center of Pulmonology, Santa Casa de Belo Horizonte. We collected $5 \mathrm{ml}$ of blood in EDTA of each patient fasting for 12 hours. Then we proceeded to samples centrifugation to obtain plasma, which was aliquoted and storaged at $-80^{\circ} \mathrm{C}$, until the analysis.

Regarding the ethical aspects of this study, we obtained the approval by the Research Ethics Committee of the Minas Gerais Federal University (CAAE - 00751512.9.0000.5149). 
Comparative analysis of the results obtained by HPLC and S-Ec methods

A comparative study between the validated HPLC methodology and by S-Ec was conductd, using Labtest Diagnóstica SA kit. The analyzes of this kit were processed at Research Laboratory of Labtest Diagnóstica using the biochemical analyzer able to read on $300 \mathrm{~nm}$ to $800 \mathrm{~nm}$ wavelengths, Labmax 560, Nishinomiya-shi, Japan.

We analyzed 68 samples of the patients above mentioned, on different days, by different operators, different techniques, and in duplicate. The statistical analyzes used for the comparison between the two methods were Anderson-Darling test, Mann-Whitney test, and Bland Altman plot performed by Minitab 16.0 and Medcalc programs.

\section{RESULTS AND DISCUSSION}

In this study, the stability of derivatized sample was evaluated by comparing the medians of Group 1 (relative area $0.69 \pm 1.69$ ) and Group 2 (relative area $0.65 \pm 1.73$ ) using Mann-Whitney test. The $p$ value $=0.377$ showed no difference between the data obtained in Groups 1 and 2 (significance level of the test is $\alpha=$ 0.05 ), which means that the derivatized sample is stable for up to 24 hours. The stability of the derivatized sample for 24 hours enabled the examination of a greater number of samples per experiment, and reinjection was performed when necessary.

\section{Method validation}

The chromatographic profile obtained after the analytical parameters were optimized for the quantification of plasma homocysteine by HPLC is shown in Figure 1. We observed that the optimum conditions were suitable to obtain a good separation of homocysteine and IS (cystamine), even in the presence of two interfering. The total runing time was 10 minutes, flow $1.1 \mathrm{ml} / \mathrm{min}$.

The linearity was studied in seven levels, prepared in independent quintuplicates in the matrix (plasma pool) and

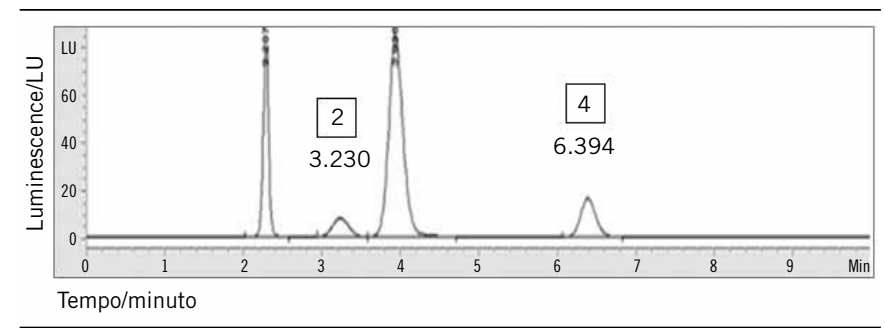

FIGURE 1 - Homocysteine chromatogram determined from analysis of plasma bomocysteine of studied patients

(2) bomocysteine analytical study; (4) cystenine analytical study. in deionized water in equally spaced range of 5 to $125 \mu \mathrm{mol} / \mathrm{l}$. Points ranging from $105 \mu \mathrm{mol} / \mathrm{l}$ to $125 \mu \mathrm{mol} / \mathrm{l}$ were not normally distributed in aqueous curves and in matrix, therefore they were excluded from the analysis. The interval 5 to 85 was submitted to outliers analysis, and one outlier was removed from curve in matrix (corresponding to the concentration $45 \mu \mathrm{mol} / \mathrm{l}$ ), and another one in aqueous curve (corresponding to the concentration $85 \mu \mathrm{mol} / \mathrm{l})$, obtaining the equation of a line and the coefficient of determination ( $\left.\mathrm{y}=0.03048 \mathrm{x}+0.008827 ; r^{2}=0.99904\right)$ for the aqueous curve, and $\left(\mathrm{y}=0.03002+0.02387 ; r^{2}=0.99835\right)$ for the curve in matrix. Then, the Shapiro Wilk test showed that residues followed a normal distribution $(p=0.460$ for the curve in matrix, and $p=0.107$ for the aqueous curve; test significance is $\alpha=0.05)$. The significant regression $(p<0.001)$ and the intercept $(\beta 0)$ different from zero indicated that the range from 5 to $85 \mu \mathrm{mol} / \mathrm{l}$ of homocysteine was linear.

The matrix effect was evaluated on the linear range, indicating that the method did not present it $(\phi<0.001$ for Levene test and $t$-test).

The choice of concentrations for accuracy and precision of the method covered normal values of homocysteine and hiperhomocysteinemia, and five different concentrations over the linear range of the method were proposed.

The intra and inter-assay precision (partial reproducibility) of method were expressed by the coeficient of variation values shown in Table 2.

TABLE 2 - Evaluation of the precision of homocysteine by HPLC method

\begin{tabular}{ccc}
\hline \multirow{2}{*}{$\begin{array}{c}\text { Homocysteine } \\
\text { concentration }(\mu \mathrm{mol} / \mathrm{l})\end{array}$} & \multicolumn{2}{c}{ Coefficient of variation } \\
\cline { 2 - 3 } & Intra $(\%)$ & Inter $(\%)$ \\
\hline 10.0 & 4.3 & 7.1 \\
15.0 & 4.6 & 8.0 \\
30.0 & 5.5 & 7.9 \\
40.0 & 4.0 & 5.8 \\
75.0 & 2.9 & 6.2 \\
\hline
\end{tabular}

Relative standard deviation intra-assay $(\mathrm{n}=5)$ and inter-assay $(\mathrm{n}=3$ days; $\mathrm{n}=5$ replicates).

HPLC: bigh-performance liquid chromatography.

In inter-assy precision, evaluated by two different analysts, the normality of data was confirmed by Anderson-Darling test $(p>0.05)$. There was equality in means of the differences obtained from the same analyst, and between analysts 1 and 2 by $t$-test $(\phi>0.05)$.

Method recovery presented values between $(89.6 \pm 3.5 \%)$ and $(104.5 \pm 4.2 \%)$ as shown in como Table 3. The results obtained 
TABLE 3 - Evaluation of the accuracy of homocysteine by HPLC method, evaluated through method recovery, by CAP interlaboratory programme analysis and Biorad internal control

\begin{tabular}{|c|c|c|c|c|c|c|c|}
\hline \multicolumn{8}{|c|}{ Accuracy } \\
\hline \multicolumn{2}{|c|}{ Recuperation } & \multicolumn{3}{|c|}{ CAP } & \multicolumn{3}{|c|}{ BIORAD } \\
\hline $\begin{array}{l}\text { Homocysteine } \\
\text { concentration } \\
\quad(\mu \mathrm{mol} / \mathrm{l})\end{array}$ & $(\%)$ & Sample & $\begin{array}{c}\text { Homocysteine } \\
\text { concentration } \\
(\mu \mathrm{mol} / \mathrm{l})\end{array}$ & $\begin{array}{c}\text { Acceptance range } \\
(\mu \mathrm{mol} / \mathrm{l})\end{array}$ & Level & $\begin{array}{c}\text { Homocysteine } \\
\text { concentration } \\
(\mu \mathrm{mol} / \mathrm{l})\end{array}$ & $\begin{array}{c}\text { Acceptance range } \\
(\mu \mathrm{mol} / \mathrm{l})\end{array}$ \\
\hline \multirow{2}{*}{10.0} & \multirow{2}{*}{$98.7 \pm 6.8$} & \multirow{2}{*}{ CAP 1} & 13.2 & \multirow{2}{*}{$10.8-15.1$} & \multirow{3}{*}{ CAP 1} & \multirow{3}{*}{$9.64 \pm 0.84$} & \multirow{3}{*}{$9.70 \pm 2.40$} \\
\hline & & & 13.7 & & & & \\
\hline 15.0 & $89.6 \pm 3.5$ & \multirow{2}{*}{ CAP 2} & 5.3 & \multirow{2}{*}{$3.4-6.6$} & & & \\
\hline 30.0 & $96.6 \pm 4.5$ & & 5.5 & & \multirow{3}{*}{ CAP 2} & \multirow{3}{*}{$26.2 \pm 1.14$} & \multirow{3}{*}{$28.2 \pm 5.7$} \\
\hline 40.0 & $104.5 \pm 4.2$ & \multirow{2}{*}{ CAP 3} & 23.6 & \multirow{2}{*}{$21.2-27.3$} & & & \\
\hline 75.0 & $100.0 \pm 7.5$ & & 23.2 & & & & \\
\hline
\end{tabular}

CAP 1, 2, and 3: three concentration levels sent by the provider; BIORAD: level 1 (normal) and level 2 (pathological).

HPLC: high-performance liquid chromatography; CAP: College of American Pathology.

by CAP interlaboratorial program and the results obtained by Bio-Rad internal control were satisfactory and contributed to strengthen confidence in the validated method.

The detection and quantification limits of HPLC method were foram $1.0 \mu \mathrm{mol} / \mathrm{l}$ and $3.4 \mu \mathrm{mol} / \mathrm{l}$, respectively.

Regarding robustness, the proposed variations had strategic objectives, in which the addition of methanol to the mobile phase was carried out to reduce the running time of analysis without overlaping the analytical signals. The decreases in SBDF and TCEP concentrations were proposed to reduce the cost of analysis, because among the reagents used these are the most expensive. The increase in precipitant agent (TCA-EDTA) concentration was performed in order to obtain a cleaner supernatant. The increase of rotation and decrease of rotation time were proposed aiming to decrease sample preparation time. Eventually, bath temperature was tested in order to evaluate a potential change in homocysteine derivatization procedure.

Youden test was used and the statistical confirmation by F-test and $t$-test showed that the influence of variations was not significant ( $\phi>0.05$ for each parameter evaluated). The validated method was considered robust due to the small variation proposed.

\section{Comparative analysis}

The comparative analysis of the results from plasma homocysteine levels was performed using both techniques: Mann-Whitney test and by Bland \& Altman plot (Figure 2). The Mann-Whitney test showed that data are comparable, and no difference was found between results $(\phi>0.05)$. The Bland \& Altman plot showed that mean $(\mu=-0.817)$ is close to zero, suggesting that the techniques are consistent with each other. The

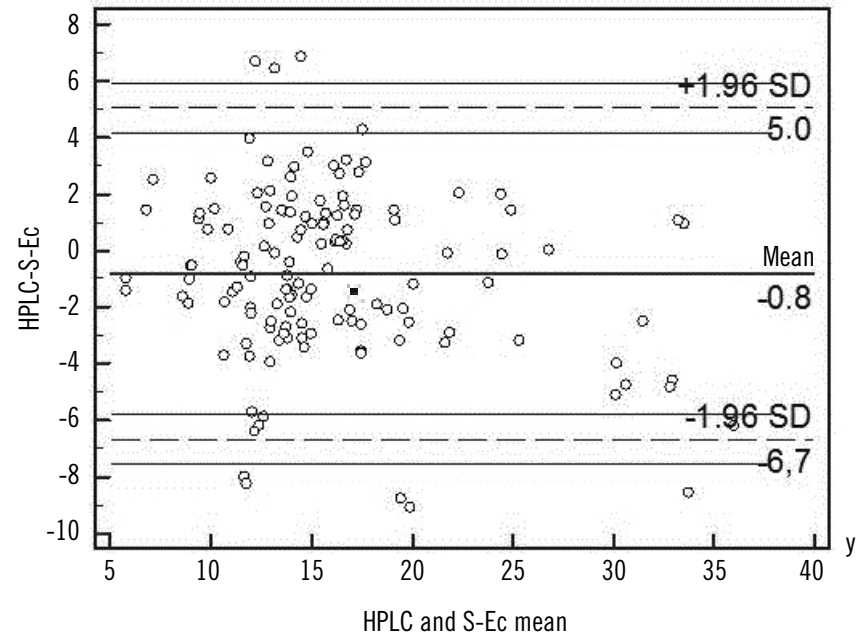

FIGURE 2 - Bland-Altman plot to evaluate the results determined by HPLC and S-EC $X$-axis represents the concentration means obtained in the replicates of both techniques, and $Y$-axis represents the concentration difference obtained between HPLC and S-Ec results. HPLC: high-performance liquid chromatography; $S$-Ec: spectrophotometric enzymatic cycling; SD: standard deviation represented by the dashed line; Mean: mean represented by the solid line.

dispersion of differences between data is not biased, and much of it is distributed around the mean. Therefore, S-Ec may be an option in the homocysteine analysis in clinical laboratories, since it demands less laboratorial expertise.

Some studies evaluating the techniques for the determination of homocysteine are described in the literature. For example, Gascón et al. $(2010)^{(9)}$ evaluated the automated chemiluminescence technique, and La'ulu et al. (2008) ${ }^{(15)}$ evaluated six automated methods. In both studies, the results were comparable with those obtained by HPLC, and presented good correlation between them. 
We can assume that S-Ec use represents an option to the laboratory due to its easy performing, quick analysis, and reliability of result.

To choose the method to be adopted in a laboratory, it is important to know and analyze the advantages and disadvantages of each method. Although HPLC is considered the gold standard for the determination of homocysteine, we highlight that the sample preparation in totally manual and involves several steps. The enzymatic cycling method, in turn, requires a photometer able to read at $340 \mathrm{~nm}$ and requires no sample preparation. The reaction consists in the reduction of homocysteine followed by enzymecatalyzed steps that promote the oxidation of nicotinamide adenine dinucleotide reduced form (NADH) in nicotinamide adenine dinucleotide (NAD) and consequent reduction of optical activity at $340 \mathrm{~nm}$. The cyclic reaction allows the response amplification in the system. The time spent on sample preparation for validated HPLC method for quantification of homocysteine is about 2 hours, while in S-Ec methodology the total release time is 10 minutes. This factor is critical to the laboratory since the streamlined execution contributes to decrease the release time of the result to the patient, and also enable to process a greater number of samples per day. The validated HPLC method presents a greater work range and analytical sensitivity (linearity up to $85.0 \mu \mathrm{mol} / \mathrm{l}$ and limit of detection $1.0 \mu \mathrm{mol} / \mathrm{l}$ ) when compared to S-Ec (linearity 50.0 $\mu \mathrm{mol} / \mathrm{l}$ and limit of detection $1.74 \mu \mathrm{mol} / \mathrm{l})$. The kit manufacturer mentions the possibility of making dilutions of the samples that giving values above $50 \mu \mathrm{mol} / \mathrm{l}$, as an alternative to release higher homocysteine results.

To date, there are no commercial kits for homocysteine by HPLC, therefore the method validation, as well as the preparation of all reagents are required in any laboratoriy that choose this method. This factor may contribute to increasing the varyiation of results. Chromatography is a separation technique of similar substances, is sensitive and requires the sample to be introduced into chromatograph as "cleanest" as possible (extraction of the compounds of interest), in order to preserve its components.

It is difficult to evaluate HPLC regarding the cost/benefit ratio, since this will depend on each laboratory facilities, as well as the team qualifications of it, required demand, purchasing power, etc. Chromatography equipment is costly, restricted to specific analyzes, not very easy handling, and requires trained staff. On the other hand, S-Ec methodology uses an automated analyzer that can also be used in many other analyses of other analytes in the laboratory; it is easy handling, which encourages more assimilation of the operating staff. The laboratory opportunity to obtain the equipment by lending, make the implementation and acquisition of this method easier.

It is expected that the considerations throughout this study can contribute to bring advances in issues concerning the determination of this amino acid in clinical laboratories.

\section{CONCLUSION}

The study allows us to validate HPLC method for quantification of plasma homocysteine, showing satisfactory robustness, and suitables precision, accuracy, and sensitivity.

S-Ec methodology showed that it can to be an option for automated method for clinical laboratories; its performance is comparable with the validate HPLC method.

\section{RESUMO}

Introdução e objetivo: A determinação dos níveis plasmáticos de homocisteína tem sido relatada como um marcador de risco de interesse em doenças graves que cursam com lesões endoteliais, estando associada ao desenvolvimento ou à progressão de lesões ateroscleróticas e formação de trombos. Os objetivos do presente estudo compreenderam validar o método de dosagem de homocisteina plasmática por cromatografia líquida de alta eficiência (CLAE) com detecção fluorimétrica, analisar amostras de pacientes com hipertensão pulmonar e comparar os resultados obtidos por CLAE com aqueles obtidos com a metodologia espectrofotométrica enzimática cíclica (E-Ec). Materiais e métodos: Osparâmetros de validação linearidade, efeito de matriz, precisão, exatidão, limites de detecção e quantificação, além de robustez do método foram avaliados visando demonstrar que este está apropriado para o uso pretendido. Os dados obtidos na quantificação de homocisteína pelo método validado (CLAE) epela metodologia espectrofotométrica enzimática cíclica (kit da Labtest) foram comparados. Resultados: O método mostrou-sepreciso, exato, robusto, com boa recuperação e não apresentou efeito de matriz. A linearidade abrangeu a faixa de 5 a 85 нmolll, e os limites de detecção e quantificação foram $1 \mu \mathrm{mol} / \mathrm{l}$ e 3,4 $\mu \mathrm{mol} / \mathrm{l}$, respectivamente. Quanto à comparação dos resultados da determinação de homocisteina por CLAE e por E-Ec, eles foram comparáveis. Conclusão: 0 método validado por CLAE apresentou desempenho adequado para mensuração dos níveis plasmáticos de homocisteína, enquanto o uso da metodologia E-Ec forneceu resultadospara homocisteina comparáveis com aqueles obtidos pelo método validado, sendo esta metodologia uma opção de método automatizado para laboratórios clínicos.

Unitermos: homocisteina; cromatografia líquida de alta eficiência; metodologia espectrofotométrica enzimática cíclica. 


\section{REFERENCES}

1. ABNT. Associação Brasileira de Normas Técnicas. NBR ISO/IEC 17025. Requisitos gerais para a competência de laboratórios de ensaio e calibração. Rio de Janeiro: ISO, 2005. 31p.

2. AMORIM, F. G. et al. Bioquímica clínica da aterosclerose provocada por hiper-homocisteinemia. Revista Eletrônica de Farmácia, v. 8, n. 1, p. 36-59, 2011.

3. ARROLIGA, A. C. et al. Association between hyperhomocysteinemia and primary pulmonary hypertension. Respiratory Medicine, v. 97, p. 825-34, 2003.

4. BICHARA, V. M.; VENTURA, H. 0.; PERRONE, S. V. Hipertensión pulmonar: la mirada del especialista. Insuficiencia Cardiaca, v. 6, n. 2, p. 65-79, 2011.

5. BRASIL. Ministério da Saúde. Agência Nacional de Vigilância Sanitária. Resolução RE. RDC 27, de 17 de maio de 2012. Requisitos mínimos para a validação de métodos bioanalíticos empregados em estudos com fins de registro e pós-registro de medicamentos. Diário Oficial da União, Brasília, 22 maio, 2003.

6. CASSIANO, N. et al. Validação em métodos cromatográficos para análises de pequenas moléculas em matrizes biológicas. Química Nova, v. 32, n. 4, p. 1021-30, 2009.

7. CHICHIZOLA, C. et al. El valor diagnóstico de La homocisteina. Revista Argent Endocrinol Metab, v. 40, n. 1, p. 32-42, 2003.

8. DUBSKÁ, L.; HYÁNEK, J. Stanovení homocysteinu v biologickém materiálu. Klin Biochem Metab, v. 17, n. 38, p. 93-5, 2009.

9. GASCÓN, M. T. et al. Avaliação do método de quimioluminescência na análise de homocisteína plasmática e sua comparação com o método de HPLC em amostras de crianças. Einstein, v. 8, p. 187-91, 2010.

10. GRAVINA-TADDEI, C. F. et al. Hiper-homocisteinemia como fator de risco para doença Aterosclerótica Coronariana em Idosos. Arq Bras Cardiol, v. 85, n. 3, p. 166-73, 2005.

11. GUIMARÃES, A. C. Hiper-homocisteinemia como fator de risco para doença aterosclerótica coronariana em idosos. Arq Bras Cardiol, v. 85, n. 2, p. 83-4, 2006.
12. HARBOE-GONÇALVES, L.; VAZ, L. S.; BUZZI, M. Associação entre níveis plasmáticos de homocisteína e acidente vascular cerebral isquêmico. Arquivo Neuropsiquiátrico, v. 61, n. 1, p. 97-103, 2005.

13. INMETRO. Instituto Nacional de Metrologia, Normalização e Qualidade Industrial. DOQ-CGCRE-008. Orientação sobre validação de métodos analíticos. Rio de Janeiro: INMETRO, 2011. 20p.

14. KAPRAL, A. et al. Homocysteinemia and ovariectomy-initial experience with funcitional monitoring. Ceska Gynekol, v. 67, n. 6, p. 328-32, 2002.

15. LA'ULU, S. L. et al. Performance characteristics of six homcysteine assays. Am J Clin Pathol, v. 130, p. 969-75, 2008.

16. MALINOW, M. R. Plasma homocyst(e)ine and arterial occlusive diseases: a mini-review. Clin Chem, v. 40, n. 1, p. 173-6, 1995.

17. MCCULLY, K. S. Vascular pathology of homocysteinemia: implications for the pathogenesis of arteriosclerosis. Am J Pathol, v. 56, n. 1, p. 111-28, 1969.

18. NETO, A. C. et al. Nível plasmático de homocisteína: marcador de gravidade em pacientes sépticos? Rev Bras Ter Intensiva, v. 22, p. 327-32, 2010.

19. OZEROL, I. H. et al. Plasma endothelin-1, homocysteine and serum nitric oxide values in Patients with left-to-right shunt. Indian Heart J, v. 56, p. 653-7, 2004.

20. PFEIFFER, C. M.; HUFF, L. D.; GUNTER, W. Rapid and accurate HPLC assay for plasma total homocysteine and cysteine in a clinical laboratory setting. Clinical Chemistry, v. 45, p. 290-2, 1999.

21. RIBANI, M. et al. Validação em métodos cromatográficos e eletroforéticos. Química Nova, v. 27, n. 5, p. 771-80, 2004.

22. SACHDEV, P. Homocisteína e transtornos psiquiátricos. Rev Bras Psiquiatr, v. 26, n. 1, p. 50-6, 2004.

23. STAUFFENBERG, M. T. et al. Hyperhomocysteinemia measured by immunoassay a valid measure of coronary artery atherosclerosis. Arch Pathol Lab Med, v. 28, p. 1263-8, 2004.

24. ZAGO, A. M.; FALCÃO, P. R.; PASQUINI, R. Hematologia fundamentos eprática. São Paulo: Atheneu, 2004.

25.ZIGHETTI, M. L. et al. Determination of total homocysteine in plasma: comparison of the Abbott IMx immunoassay with high performance liquid chromatography. Hematologica, v. 87, n. 1, p. 89-94, 2002.

\section{MAILING ADDRESS}

Tatiana Maria Costa de Campos Barbosa

Avenida Presidente Antonio Carlos; Campus Pampulha; CEP: 31270-901; Belo Horizonte-MG, Brazil; e-mail: taticam10@yahoo.com.br. 